\title{
The Impact of Organizational Learning, on Firm Performance in The Context of Manufacturing SMES in Malaysia, Mediating Role of Innovation Capability
}

Zainab Mohammed Alwan Al-Juboori, Harcharanjit Singh, Nur Naha Abu Mansor, Abdul Samad Kakar, Urooj Zulfiqar, Abdul Latif Bin Allah Pitchy

To Link this Article: http://dx.doi.org/10.6007/IJARBSS/v11-i5/9898 DOI:10.6007/IJARBSS/v11-i5/9898

Received: 16 March 2021, Revised: 20 April 2021, Accepted: 05 May 2021

Published Online: 29 May 2021

In-Text Citation: (Al-Juboori et al., 2021)

To Cite this Article: Al-Juboori, Z. M. A., Singh, H., Mansor, N. N. A., Kakar, A. S., Zulfiqar, U., \& Pitchy, A. L. B. A. (2021). The Impact of Organizational Learning, on Firm Performance in The Context of Manufacturing SMES in Malaysia, Mediating Role of Innovation Capability. International Journal of Academic Research in Business and Social Sciences, 11(5), 796-813.

Copyright: (c) 2021 The Author(s)

Published by Human Resource Management Academic Research Society (www.hrmars.com) This article is published under the Creative Commons Attribution (CC BY 4.0) license. Anyone may reproduce, distribute, translate and create derivative works of this article (for both commercial and non-commercial purposes), subject to full attribution to the original publication and authors. The full terms of this license may be seen at: http://creativecommons.org/licences/by/4.0/legalcode

Vol. 11, No. 5, 2021, Pg. 796 - 813

Full Terms \& Conditions of access and use can be found at http://hrmars.com/index.php/pages/detail/publication-ethics 


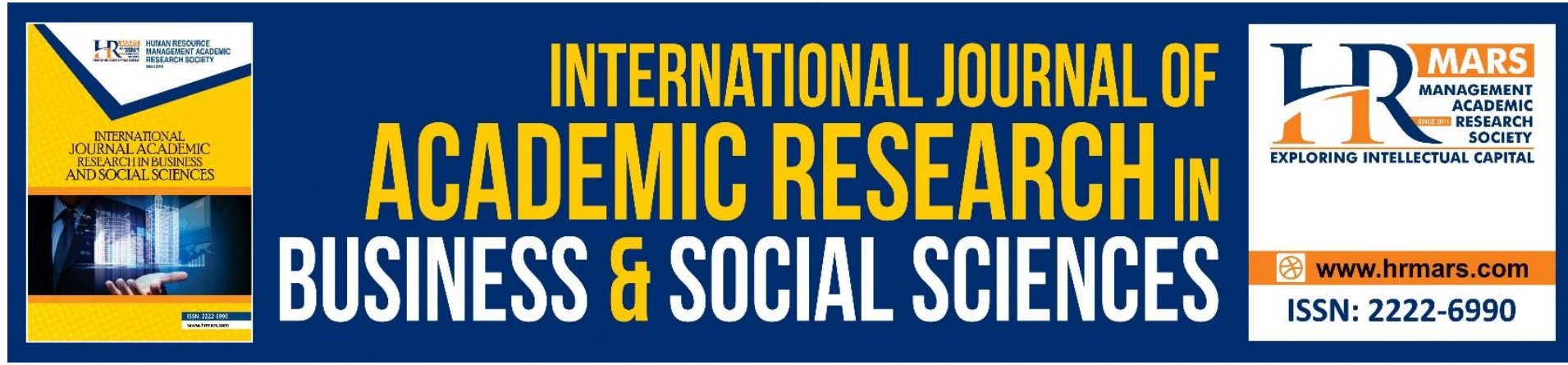

\title{
The Impact of Organizational Learning, on Firm Performance in The Context of Manufacturing SMES in Malaysia, Mediating Role of Innovation Capability
}

\author{
Zainab Mohammed Alwan Al-Juboori' ${ }^{1}$, Dr Harcharanjit Singh², \\ Nur Naha Abu Mansor ${ }^{3}$, Abdul Samad Kakar ${ }^{4}$, Urooj Zulfiqar ${ }^{5}$, \\ Abdul Latif Bin Allah Pitchy 6 \\ 1,5,6 PhD Student, Azman Hashim International Business School, Universiti Teknologi
} Malaysia, Kuala Lumpur, Malaysia, ${ }^{2}$ Senior Lecturer, Azman Hashim International Business School, Universiti Teknologi Malaysia, Kuala Lumpur, Malaysia, ${ }^{3}$ Professor, Azman Hashim International Business School, Universiti Teknologi Malaysia, ${ }^{4}$ Lecturer, University of Loralai, Pakistan, Kuala Lumpur, Malaysia.

Email: maazainab2@graduate.utm.my¹,zurooj@graduate.utm.my ${ }^{5}$, abdul.latif@graduate.utm.my ${ }^{6}$, harcharanjit@utm.my²,nurnaha@utm.my33, samadkakar87@gmail.com ${ }^{4}$

\begin{abstract}
There is a considerable signal from empirical studies that many factors influence firm performance. The purpose of this conceptual paper is to review the impact of one (1) important variable which is (organizational learning) on the performance of manufacturing SMEs operating in Malaysia. This conceptual paper explored the mediation role of innovation capability. The conceptual framework was developed after a systematic review of past literature. The present paper found the important influence of the study's variables on firm performance. Furthermore, the study provided some understanding of how organizational learning affects SMEs' performance in Malaysia. Organizational learning plays an important role in influencing a Manufacturing SME's firm performance. Despite that, the mediation role of innovation capability is expected to strengthen the relationship between organizational learning and firm performance. The paper emphasizes the critical value of organizational learning and innovation capability for SMEs owner/managers consideration when acting on behalf of their company; failing which the SMEs could experience poor performance. Resource-Based View (RBV) theory was used to underlie the conceptual framework. In addition, some implications of this conceptual model for theory and practice are discussed.
\end{abstract} Keywords: Organizational Learning, Innovation Capability, Firm Performance, Manufacturing SMEs, Malaysia 


\section{Introduction}

Since the 1990s, Small and Medium Enterprises (SMEs) have been at the center of Malaysia's financial transition to a high-income nation and are a crucial driver of both trade and growth as well as job opportunities (Auzzir, Haigh, \& Amaratunga, 2018; Gupta \& Barua, 2018; Tahir, Razak \& Rentah, 2018; Verdolini et al., 2018). In recent years, the challenges faced by SMEs regarding their overall performance have been a critical issue. In addition, SMEs have made a notable contribution to the prospects for income, production, and jobs. SMEs make a significant contribution to the financial sector and have a powerful base for developing industries. (Kamaluddin et al., 2016). Moreover, the government understands that SMEs are vital sectors of the economy and proceeds to catalyze Malaysian investment (Abdul-Halim, Ahmad, Geare \& Thurasamy, 2018). Hence, to be competitive, SMEs need to focus on the procedures, practices, ideas, and decision-making patterns that facilitate manual enterprise activities, mostly when reacting to the external environment. These SMEs must also create behavior intended to ensure that organizational outcomes and overall performance have been enhanced (Singh, Saufi, \& Hassan, 2017; Singh \& Mahmood, 2014). Although their overall performance fuels Malaysia's ongoing transition into a high-income economic system, SMEs' overall performance and sustainable development remain largely uncertain (Ghazilla, Sakundarini, Abdul-Rashid, Ayub, Olugu \& Musa, 2015). SMEs represent a large share of the Malaysian economic system's stability, it also has played a substantial role in economic growth contribution, economic empowerment, and world political sustainability in recent years. (Abdul-Halim et al., 2018).

\section{Problem Statement}

Manufacturing, SMEs in Malaysia has experienced a fluctuation in their GDP contribution from $21.7 \%$ in 2014 to $21.1 \%$ in 2018 . Past studies suggested more investigation on performance declining issues in Malaysian SMEs and the low contribution to the nation's GDP (Osman \& Ngah, 2016; Satiman, Mansor \& Zulkifli, 2015). Based on the annual report of SME Corp (2018), most of the SME sectors in Malaysia had a steady GDP growth from the year 2014 to 2018, except for the manufacturing sectors. Compared with other SME sectors such as service or construction, manufacturing SMEs face a serious issue regarding their GDP contribution and had a significant drop in their overall performance, which declined from $21.7 \%$ in 2014 to $20.1 \%$ in 2018 (SME Corp, 2018) as shown in Figure 1.

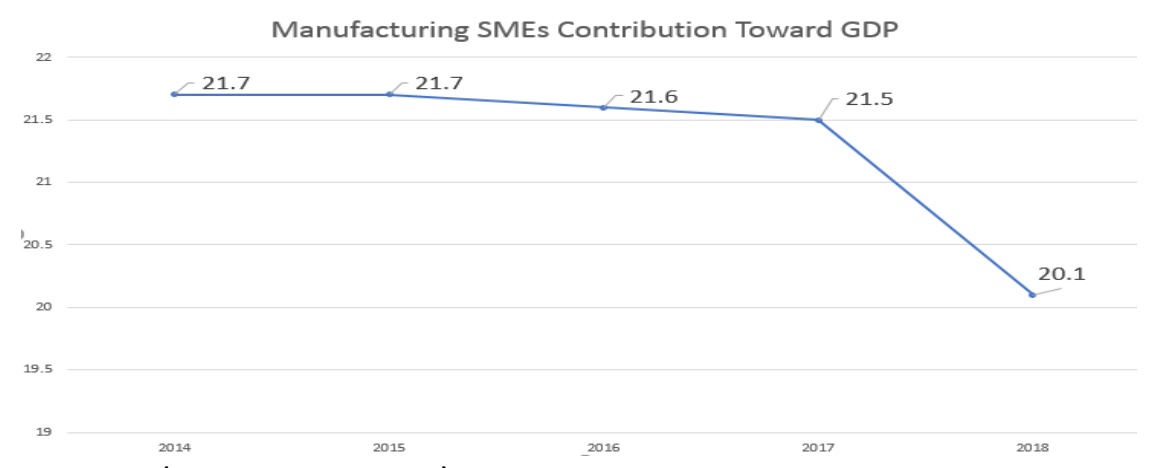

Source: (SME Corp, 2018)

Figure 1: Manufacturing SMEs Contribution to GDP Between 2014-2018

Manufacturing SMEs are the country's second-largest contributor to GDP, making them an important segment of the economy whose downturn has a significant impact on 
Malaysia's overall economy. Manufacturing SMEs are the main industry working on the transition to a low-carbon economy, and they must stay informed and mindful of their market problems. As a result, firms must continually evolve, learn how to survive, and improve, while SMEs find it impossible to upgrade and innovate without the support of corporate learning (Yusoff, Omar \& Zaman, 2019). Manufacturing SMEs in Malaysia are facing issues regarding organizational learning practices (Rehman, Bhatti \& Chaudhry, 2019). The main motive to conduct this conceptual framework is to fill the gap of Migdadi, Zaid, Yousif, Almestarihi \& AlHyari (2017), suggested future research should examine the impact of organizational learning practices on firm performance.

\section{Literature Review}

Organizational learning plays an important role in determining SME's firm performance. However, organizational learning is a critical factor within the organization in influencing their performance (Kim, Watkins \& Lu, 2017). The importance of organizational learning in SMEs has been studied by various researchers, where they paid much attention to emphasizing their studies toward organizational learning investment which helps in determining the firm overall performance (Nafei, 2015; Rehman et al., 2019; Shurafa \& Mohamed, 2016). Furthermore, organizational learning in SMEs has gone through various processes that the firm's employees have to affect the outcomes which are obtaining information, distribution of the information, and interpreting the information (Shurafa \& Mohamed, 2016). These stages help in developing the firm's capability and behaviors by using certain common experiences and acknowledging the new information development (Rehman et al., 2019). Organizational learning is an important variable that could help firms to gain competitive advantages in order to increase SME's firm performance (Kim et al., 2017). Researchers have a common belief that the ability of learning and adaptation which generally react faster and more flexibly than competitors in solving the firm's problem would enhance the strategy of a firm and lead to an increase in performance and sustainability (Yusoff, Omar \& Zaman, 2019). Several studies found a positive relationship between organizational learning and SME performance (Hooi, Ngui, 2014; Rehman et al., 2019). The present paper is based on a review of various previous studies and data gathered from the current literature. Hence, this paper will test the relationship between the constructs and focus on the effectiveness of organizational learning, and innovation capability on firm performance. Organizational learning has been widely investigated in relation to SMEs ' organizational performance (Rehman et al., 2019). Whilst recognizing the importance of the SMEs contribution to the economy, various studies have concluded that the sustainability of SMEs is heavily dependent on their competitive advantages, however, this could be accomplished through a high investment of organizational learning (Rehman et al., 2019).

\section{Research Gap}

Numerous factors contributed to SMEs' poor success in recent years, one of which is management concerns surrounding organizational learning, which has been described as a cause of low performance, decreased value, and increased financial risk for Malaysian Manufacturing SMEs. Rehman et al. (2019), suggested that future research should focus more on exploring the issues of declining in the manufacturing SMEs' performance in Malaysia. In addition, Hosseini, Wright, and Bhaskaran (2014) stated that limited knowledge exists on factors that contributed to manufacturing SMEs poor performance. Nonetheless, manufacturing SMEs in Malaysia faced a sudden drop in their financial performance due to 
management issues (Ismail, Saud \& Isa, 2017). Nonetheless, only a few researchers indicate that the poor performance of manufacturing SMEs in Malaysia is due to organizational learning (Rehman et al., 2019). According to Al Mamun, Mohiuddin, Fazal, and Ahmad (2018), there is a lack of studies that investigate the factors that influence firm performance, particularly in the context of Malaysian manufacturing SMEs. Past studies also found a positive relationship between organizational learning and innovation capability (Alegre \& Chiva, 2013; Husain, Dayan \& Benedetto, 2016; Jiménez-Jiménez \& Sanz-Valle, 2011).

However, more research is needed on the relationship between organizational learning and innovation capability according to Kafetzopoulos and Psoma (2015). They also state a limitation by illustrating the importance of the internal business environment and endogenous business factors such as organizational learning to be addressed in future studies, has not been assessed in their study. Moreover, Maldonado-Guzmán, Garza-Reyes, Pinzón-Castro, \& Kumar (2019) stated that there is a need to examine the innovation capability as a unidimensional construct toward firm performance. Maldonado-Guzmán et al. (2019), stated that future research should test the relationship between innovation capability and firm performance in other countries than Mexico to have a better understanding of the relationship. Furthermore, organizational learning and firm performance have been investigated without consistent conclusions. However, limited research had been conducted to investigate the relationship between organizational learning and firm performance, there is a need for more studies in various sectors so that findings can be generalized and more reliable (Mohammad, 2019). Moreover, Kefetzopoulos and Psomas (2015) also stated a limitation in their study by suggesting few internal business environments and endogenous business factors be addressed such as organizational learning towards firm performance. Based on the literature, there is a constant relationship between organizational learning, innovation capability, and firm performance. Based on the literature, there is a high possibility that innovation capability would mediate the relationship between organizational learning and firm performance and strengthen the relationship more. Furthermore, Migdadi et al. (2017) suggested that future researchers should investigate a new variable from a firm's characteristics mediated by innovation capability toward firm performance, such as organizational learning. Based on the discussion, the conceptual paper intends to investigate whether innovation capability mediates the relationship between organizational learning and firm performance. Hence, the following hypothesis was developed.

\section{Firm Performance}

Managing performance is important for improving limited resources, productivity, and economic value growth, prompting policymakers and public policy (Lampe \& Hilgers, 2015). Organizational performance is the core of an organization's survival (Singh, Darwish \& Potočnik, 2016), it also recognized as a fundamental predictor of management and economic analysis outcomes, ranging from diverse fields such as human resources and marketing, corporate management, international sector, strategy, and information systems (Richard, Devinney, Yip \& Johnson, 2009). Effective performance measurement enables organizations to evaluate their asset component to determine how these assets can be better supervised and transferred to the proper channels (Nawaz \& Haniffa, 2017). Over the past few decades, many innovative attempts were made to measure firm performance based on non-traditional methods. Many of them were related to an analysis of shareholder value, which involved other measures such as return on investment (ROI), economic value added (EVA), or other 
market-based indicators (Hamdan, 2018). Different performance measurement mechanisms were developed in the early 1990s to address the shortcomings of financial measures; however, these models rely mainly on intangible resources (Bourne, Mills, Wilcox, Neely \& Platts, 2000). Although measuring performance is often discussed in the literature (Inkinen, 2016), there is no general agreement on what specifically needs to be included (Neely, Gregory \& Platts, 1995). There are two (2) techniques for assessing performance: financial and non-financial, which may be evaluated using objective or subjective indicators. In addition, all the measuring tools are interdependent with the firm's productive results. Likewise, Wang, Wang, and Liang (2014) conceptualized firm performance as operational and financial performance. Despite that, the present paper will define firm performance as a financial performance which includes revenue, profit, cost reduction, return on sales, and return on assets.

\section{Organizational Learning and Innovation Capability}

Organizational learning refers to an organization's capacity to identify the need for change, adapt, and take necessary actions for competitive advantage against competitors. However, knowledge is acquired and integrated from different sources, where organizational learning creates critical insights for product innovation and managerial practices to enhance the firm performance. Employee training, experiences, and understanding the new information are called organizational learning (Narsa, 2019). Many researchers found a positive relationship between organizational learning and innovation capability (Alegre \& Chiva, 2013; Husain, Dayan \& Benedetto, 2016; Jiménez-Jiménez \& Sanz-Valle, 2011; Omar, Nazri, Alam \& Ahmad, 2016). Diverse research focuses on one source of innovation, mainly process or product innovation, or one stage of the organizational learning process, so innovation capability must be addressed as unidimensional with organizational learning (Guinot, Miralles, Rodríguez-Sánchez, \& Chiva, 2020; Yu, Zhang \& Shen, 2017). In summary, firms with a high level of organizational learning would enjoy a strong emphasis on innovation capability by investing more in the knowledge existing in a firm. This valuable knowledge would help firms to be more innovative and meet the market needs through competitive advantages and high performance. Various considerations have been examined; researchers are paying increasing attention to the possibility that organizational learning's collective capacity plays a crucial role in evaluating innovation (Senge, 1990; Senge, Roberts, Ross, Smith, \& Kleiner, 1994). Past studies found a positive connection between organizational learning and innovation capability (Senge, 1990; Senge, Roberts, Ross, Smith, \& Kleiner, 1994. Based on the literature review, past studies found a positive relationship between organizational learning and innovation capability. Thus, the following hypothesis was proposed:

$\mathbf{H}_{1}$ : There is a positive relationship between organizational learning and innovation capability

\section{Innovation Capacity and Firm Performance}

Innovation capability refers to a firm's ability to identify new ideas, transforming them into new products/services that increase firm performance. Moreover, innovation capability in a firm is an essential factor in enhancing operational reliability and enriches performance; innovation capability is a key that drives competitive advantage. Therefore, innovation capability needs to be addressed deeply in the SMEs context in Malaysia (Dzulfikar, Handayani, Syahrizal, Sensuse, Satria \& Wulandari, 2018). Innovation capability can be 
considered essential for the sustainability of aggressive advantage due to the inherent problem in imitating such merchandise (Dzulfikar et al., 2018). Innovation potential is one of the most critical factors enabling SMEs to achieve a high degree of profitability on both the domestic and foreign markets. Promoting and maintaining an increased capacity for innovation will be the main priority of the SME's managers (Hussein, Singh, Farou \& Sohal, 2016). Thus, for a firm to enjoy superior performance, it has been suggested that innovation capability should respond faster to the customer's need, and that would be accomplished through high emphasis on innovation (Hamid \& Gharneh, 2017). Past research on large and small to medium-sized businesses found a positive relationship between innovation capability and market success (Omar et al., 2016; Pongsathornwiwat et al., 2019). Meanwhile, Donkor, Donkor, Kankam-Kwarteng, and Aidoo (2018) reported that innovation capability has a high correlation with firm performance. Besides that, Kafetzopoulos and Psomas (2015) suggested that more analytical and methodological research is needed to analyze the impact of overall innovation capacity on firm performance, and they found a positive correlation between innovation capability and operational performance. Naala, Nordin, and Omar (2017) found a positive relationship between innovation capability and SMEs performance. Based on the literature review many past studies found a positive relationship between innovation capability and firm performance. Thus, the following hypothesis was proposed:

$\mathbf{H}_{\mathbf{2}}$ : There is a positive relationship between innovation capability and firm performance

\section{Organizational Learning and Firm Performance}

Firm performance refers to extent of a firm ability to achieve its financial performance in terms of revenue, profit, cost reduction, return on assets, and sales. However, organizational learning is a key resource to enhance studying capacity amongst people and agencies to compete within the market. According to Zgrzywa-Ziemak (2015), organizational learning promotes its activities in re-building the organizational structure and work system to increase innovation capacity. Moreover, the process where employees of a firm can impact the firm's development and behaviors through the usage of their shared experience and understanding of new information development would establish through organizational learning. Organizational learning is an important instrument in gaining sustainable competitive advantage and superior firm performance (Kalmuk \& Acar, 2015). Mohammad (2019) found that organizational learning influences the performance of manufacturing firms. Crosscultural research has reported a strong positive relationship between organizational learning on financial and non-financial performance (Zandi \& Sulaiman, 2015). Based on the literature review there is a positive relationship between organizational learning and firm performance. Thus, the following hypothesis was proposed:

$\mathbf{H}_{3}$ : There is a positive relationship between organizational leaning and firm performance

\section{Mediation Role of Innovation Capability}

Innovation performs an essential function in ensuring organizational survival and competitive advantages by continuously producing new products or services. Despite that, researchers suggested that innovation capability has a strong influence on firm performance (Dzulfikar, Handayani, Syahrizal, Sensuse, Satria \& Wulandari, 2018). Innovative distinctive competencies and organizational learning positively affect organizational performance, directly and indirectly through organizational innovation (BolíVar-Ramos, GarcíA-Morales \& 
GarcíA-SáNchez, 2012). Organizational learning is needed when an organization must respond to changes in the environment or identifies errors, and correct them (Guinot, Miralles, Rodríguez-Sánchez \& Chiva, 2020; Rehman et al., 2019).

Several studies discovered that organizational learning contributes to stabilizing firm performance. Nonetheless, the ability to learn and integrate organizational learning is evident in teamwork and in transforming a robust innovation capability, which provides a firm with long-term sustainability as its customers perceive its innovativeness towards firm performance (Abdi, Mardani, Senin, Tupenaite, Naimaviciene, Kanapeckiene \& Kutut, 2018; Maktabi \& Khazaei, 2014). Alegre and Chiva (2013) found in their empirical study that organizational learning affects innovation capability which in turn affects the firm performance. Organizational learning appears to contribute to innovation capacity, and innovation is positively linked to firm performance (Maktabi \& Khazaei, 2014). Hence, it is critical in all types of industries for the firm to turn its organizational learning into a creative solution rapidly. Innovation is incorporating company processes, workplace organizations, or external relations of a new or substantially changed product (goods or service), operation, a new communication strategy, or a new organizational system (Tuan, Nhan, Giang \& Ngoc, 2016). Literature review on innovation capability suggests that every organization needs creativity to grow and survive (Damanpour, 1991; Gopalakrishnan \& Damanpour, 1997) and gain a sustainable competitive advantage (Standing \& Kiniti, 2011). Based on the literature review, there is a positive relationship between organizational learning and innovation capability, at the same time between innovation capability and firm performance. Present research posits that when the organizational learning activities it will increase firm innovation capability; when firm innovation capability increases it will increase firm performance. Thus, there is a high possibility that innovation capability could strengthen the relationship between organizational learning and firm performance. Thus, the following hypothesis was proposed:

$\mathbf{H}_{4}$ : Innovation capability mediate the relationship between organizational learning and firm performance

\section{Research Design \& Method}

Design and layout were previously known to be one of the firm's features in previous studies, however, the manufacturing industry's physical environment includes its system design and layout (Rehman et al., 2019). The design/layout of an atmosphere assists customers in orienting themselves, learning and finding their way around signs, and gaining personal feelings and influence (Bitner, 1992). Hence, certain features, influence customer's attitudes towards product providers in the production settings (Bitner, 1992). This conceptual paper was developed through a systematic literature review method. The literature review was synthesized based on scholarly literature pertaining to organizational learning as well as the mediation role of innovation capability and its impact on firm performance as shown in (Figure 2). The present conceptual paper developed four (4) hypotheses to test the relationship of organizational learning, and innovation capability towards firm performance. Future researchers could use a quantitative approach to examine this relationship empirically. Similarly, two (2) underpinning theories, resource-based view theory can be utilized to underpin the research framework. The conceptual paper process went through a rigorous, standardized methodology for conducting a systematic review. The proposed conceptual framework may have tested empirically using the quantitative method in the future. 


\section{Underpinning Theories}

Wernerfelt (1984) established the Resource-Based View theory as an enhancement to the previous authors to clarify the theory. Most organizations recognize the principle of RBV. Moreover, Peteraf (1993) has provided a summary of the RBV that could help bring out the equilibrium orientation of the RBV. Based on the RBV prospective company's operational resources, such as vital resources, and how these resources are fully exploited to gain competitive advantage and achieved superior performance (Al-Musali \& Ku, Ismail, 2014). The company's RBV characterizes an organization as a set of resources and views it as the foundation for a business's strategic advantage. The firm is aiming to have a sustainable competitive advantage due to the fact it helps in cost reduction. According to Foss and Foss (2004), RBV theory plays an important role in improving the competitive advantages by utilizing the firm's resources in a way that could reduce the cost and improve the product quality. Based on the RBV perspective, the company views knowledge as a distinctly unique resource (Kogut \& Zander, 1992). Which would reflect organizational learning as one of these valuable resources (Medsker, Williams \& Holahan, 1994).

\section{Resource-based View (RBV) Theory and Organizational Learning}

Organizational learning is an effective technique to business challenges that allows a flexible version that hastes the industry growth (Mantok, Sekhon, Sahi \& Jones, 2019). Based on the RBV theory by Barney (1991), through organizational learning, firms can utilize their people and achieve a competitive advantage, resulting in better performance (Kang, Morris, \& Snell, 2007). Organizational learning of a firm can develop hard to imitate knowledge resources and capabilities that create value, leading to superior performance. Empirical research on organizational learning has used various theories, such as organizational learning theory (Siddique, 2018), knowledge creation theory (Brix, 2017), and stakeholder theory (ValdezJuárez, Gallardo-Vázquez \& Ramos-Escobar, 2019). However, the (RBV) theory gained much attention and recognition in organizational learning research. Many researchers argued that (RBV) theory is the most suitable theory used to test the impact of a broad aspect of the possible positive impact of organizational learning in a firm (Dada \& Fogg, 2016; Hooi \& Ngui, 2014; Rehman et al., 2019). Besides that, effective utilization of organizational learning could help firms to achieve competitive advantages by increasing the product quality and reducing the cost that eventually helps to attain competitive advantages for superior performance (Rehman et al., 2019; Yusoff et al., 2019).

\section{Resource-based View (RBV) Theory and Innovation Capability}

Innovation capability is a critical capability in a firm that deploys resources with a new capacity to create value. Innovation capability regarded as a process involving the interaction of many different resources. Hence, successful innovation relies on firms' resources. Saunila (2016) indicated that resource commitment is positively related to innovation capability. Various studies have expressed innovation capacity as the organization's future ability to position itself in a world of modernism such as creative product development, technical and other developments leading to a competitive advantage over its rival (Hussein et al., 2016). Based on the competitive advantage premise, RBV theory argued that company internal resources such as innovation processes can be exploited in order to develop rare and inimitable products or services to beat the competitors and reach superior performance (De Stefano, Montes-Sancho \& Busch, 2016; Donkor et al., 2018). 
Moreover, the company should be creative in its attitude towards the regulations, as more responsive regulations will enable them to adapt their responses to their own needs and to find new ways of fulfilling their duties to enjoy competitive advantages (Giménez, Guijarro Duréndez, 2019; Huhtala, Sihvonen, Frosen, Jaakkola \& Tikkanen, 2014). Many past researchers have used different theories regarding innovation capability where Racela and Thoumrungroje (2019), used resource advantage theory. However, the most theory used with innovation capability was (RBV) theory such as (Aini et al., 2013; Alam, Munizu \& Jillbert, 2019; Al-kalouti et al., 2020; Hamidi \& Gharneh, 2017; Hoang \& Ngoc, 2019; Mir, Casadesús \& Petnji, 2016; Naala et al., 2017; Omar et al., 2016; Taherparvar, Esmaeilpour \& Dostar, 2014)

\section{Resource-based View (RBV) Theory and Firm Performance}

Past researchers have studied the linkage between the firm's resources and firm performance (Chavez, Jacobs \& Feng, 2017; Ford \& Paladino, 2013). Researchers have utilized (RBV) theory to explain the firm resources (Ford \& Paladino, 2013; Penrose, 1959) and the difference in the firm performance, which has engaged in competitive advantages (Rađenović \& Krstić, 2017). Empirical researchers support the view that differences in quality and quantity of resources lead to differences in performance and allocation of adequate resources, imperative for firm success (Rađenović \& Krstić, 2017). The positive relationship between resource allocation and firm performance was further advanced in the literature by Rađenović and Krstić (2017). They recommended that resources derived from the unique strategies' capabilities can result in considerably superior performance.

\section{Research Design/Methodology/Approach}

A systematic review was conducted by five (5) reviewers who focus on the acquisition and synthesis of information blindly and in tandem. Furthermore, the review approach was welldeveloped in order to reduce biases and exclude obsolete or low-quality research. The first step in a systematic analysis is to properly formulate the study topic, which is accompanied by the introduction of a procedure. Furthermore, it is important to do a rigorous and comprehensive literature review by using a systematic review strategy. As a result, we'll have access to all findings, even those that are especially relevant to our work. That is why a rigorous, factual, and repeatable literature review is required; characteristics distinguish a systematic review from a conventional narrative study. Following the selection of studies an accurate, comprehensive, and systematized compilation of all knowledge provided in each published paper was discussed.

\section{Results and Discussion}

The conceptual paper was built using a comprehensive analysis of journal papers, proceedings, conferences, and books relevant to the keywords and study field. The following theoretical structure was developed based on the scope of the literature review and study discrepancy (Figure 2). 
H3

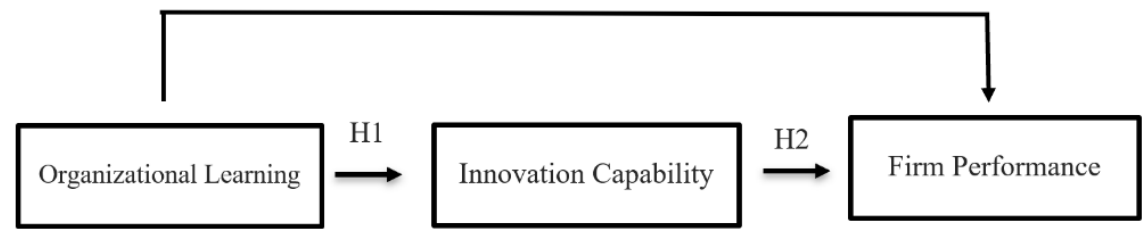

$\mathrm{H} 4$

Figure2: Conceptual Framework

Based on the literature review; many past studies mostly found that organizational learning and innovation capability have a positive influence on firm performance. Thus, when organizational learning and innovation capability activities increase; this will also improve the Manufacturing SME's firm performance. Moreover, the relationship between organizational earning and firm performance is expected to be strong, however, this relationship expected to be strengthened and stronger with the mediation effect of innovation capability.

\section{Integrative Framework}

In recent years, there has been a major increase in non-physical factors research in Malaysian manufacturing industries, especially in SMEs. Consequently, manufacturing industries are growing in numbers globally and fortunately, this is the fastest growing industry among other industries, which overlooked by researchers. In particular, the majority of studies on organizational learning and innovation capability in Malaysian SMEs are primarily focused on various sectors ignoring the critical and significant sectors to the Malaysian GDP which is the manufacturing industry (Khalique, Bontis, Shaari, Yaacob \& Ngah, 2018). Moreover, this conceptual paper demonstrates the importance of organizational learning and innovation capability toward SMEs' performance in Malaysia. The present conceptual paper will contribute to the body of knowledge in the management field, specifically organizational learning and innovation capability and its relationships on firm performance.

This conceptual paper could help owner/managers of manufacturing SMEs in Malaysia to have a broader understanding of the relationship between organizational learning and the mediator effect of innovation capability toward firm performance and know-how to utilize their resources effectively for better performance. However, several advantages can be derived from the implementation of organizational learning (Rehman et al., 2019) and innovation capability (Kafetzopoulos \& Psomas, 2015). The expected result of this conceptual paper is to find a positive connection between the study variables and firm performance which could eventually draw a conclusion of the importance of organizational learning on firm performance. Furthermore, the innovation capability expected to strengthen the relationship between organizational learning and firm performance and contribute as a positive mediator in the study. Moreover, past literature has been approved in enhancing the firm's performance and improved relations with stakeholders and clients. 


\section{Implications of the study}

This paper acts as a platform for Manufacturing SMEs and the Malaysian government to place a greater and revived emphasis on facets of firm success and their determinants. The current conceptual paper can conclude that organizational learning and innovation capability are significant antecedents of firm success based on the results of previous studies. The conceptual framework has not been tested empirically. Future research could have considered other influencer factors such as knowledge management and process management. Future studies may consider other independent variables such as innovation performance and moderating variables such as innovation speed and test them empirically. Additionally, this study also depicts that innovation capability is mediated by the relationship between organizational learning toward firm performance. Future research may also conduct a comparative study on SMEs' organizational learning in Malaysia on environmental concerns, such as environmental performance. Future research may also explore the impact of other independent, mediating, or moderating variables that could extend the present paper's theoretical model.

\section{Conclusion}

This conceptual paper focuses on organizational and its impact on firm performance. Moreover, it also tests the mediation effect of innovation capability between organizational learning and firm performance. High emphasis on organizational learning in Malaysian SMEs would also motivate other firms in utilizing the firm's resources efficiently. The present conceptual paper explained how organizational learning and innovation capability could be used to generate superior performance. Firms should effectively exploit their firm's resources to enjoy superior performance. Hence, by looking at the fast-changing market trends and the competitive market, SMEs need to have numerous strategies to provide a better competitive advantage in producing better products or services to satisfy their customers' needs. This paper will provide an impetus for Manufacturing SMEs owner/managers and the government of Malaysia to give greater and renewed focus to the aspects of firm performance and its influencers. Based on the past literature and findings, the present study can argue that organizational learning and innovation capability are important antecedents of firm performance.

\section{Theoretical and Contextual Contribution}

The present paper gives a brief understanding about the significant impact of organizational learning on firm performance and how innovation capability could strengthen the relationship. The present conceptual paper contributed to the body of knowledge in the field of organizational learning and innovation capability. However, present paper proved its significant contribution in the context of manufacturing SMEs in Malaysia toward firm performance by addressing the problem of performance declining through their low GDP contribution which has not been addressed by past studies yet. Hence, present paper enhances the knowledge of Migdadi et al. (2017), who recommended to expand their framework by testing new variable such as organizational learning mediated by innovation capability on firm performance. Present conceptual paper will provide valuable information and create awareness to the owner/managers of manufacturing SMEs in Malaysia regarding organizational learning practices which could improve their overall firm performance. Consequently, the paper extends the current body of knowledge in both theoretical and practical areas. Moreover, organizational learning and innovation capability have an obvious 
influence on firm performance based on past literatures, and by investing more in these factors, firm performance will be improved. Furthermore, present paper provides un-tested framework in the context of manufacturing firms in Malaysia and worldwide, which gives an opportunity to the future researchers to examine it empirically. Present conceptual framework also provides a validation to the theory of resource-based view (RBV).

\section{References}

Abdi, K., Mardani, A., Senin, A. A., Tupenaite, L., Naimaviciene, J., Kanapeckiene, L., \& Kutut, V. (2018). The effect of knowledge management, organizational culture and organizational learning on innovation in automotive industry. Journal of Business Economics and Management, 19(1), 1-19.

Abdul-Halim, H., Ahmad, N. H., Geare, A., \& Thurasamy, R. (2018). Innovation culture in SMEs: The importance of organizational culture, organizational learning and market orientation. Entrepreneurship Research Journal, 9(3).

Aini, E. K., Shen, D. C. L., Al Musadieq, M., \& Handayani, S. R. (2013). The role of innovation capability on business performance at small medium enterprises. PROFIT: JURNAL ADMINISTRASI BISNIS, 7(1).

Al-kalouti, J., Kumar, V., Kumar, N., Garza-Reyes, J. A., Upadhyay, A., \& Zwiegelaar, J. B. (2020). Investigating innovation capability and organizational performance in service firms. Strategic Change, 29(1), 103-113.

Al-Musali, M. A. K., \& Ismail, K. N. I. K. (2014). Intellectual capital and its effect on financial performance of banks: Evidence from Saudi Arabia. Procedia-Social and Behavioral Sciences, 164, 201-207.

Al Mamun, A., Mohiuddin, M., Fazal, S. A., \& Ahmad, G. B. (2018). Effect of entrepreneurial and market orientation on consumer engagement and performance of manufacturing SMEs. Management Research Review.

Alam, S., Munizu, M., \& Jillbert, J. (2019, February). Effect of use of information technology on innovation capability, competitiveness, and firm performance: Case of manufacturing industry in South Sulawesi. In IOP Conference Series: Earth and Environmental Science (Vol. 235, No. 1, p. 012008). IOP Publishing.

Alegre, J., \& Chiva, R. (2013). Linking entrepreneurial orientation and firm performance: The role of organizational learning capability and innovation performance. Journal of small business management, 51(4), 491-507.

Auzzir, Z., Haigh, R., \& Amaratunga, D. (2018). Impacts of disaster to SMEs in Malaysia. Procedia engineering, 212, 1131-1138.

Barney, J. (1991). Firm resources and sustained competitive advantage. Journal of management, 17(1), 99-120.

Bitner, M. J. (1992). Servicescapes: The impact of physical surroundings on customers and employees. Journal of marketing, 56(2), 57-71.

Bolívar-Ramos, M. T., Garcia-Morales, V. J., \& García-Sánchez, E. (2012). Technological distinctive competencies and organizational learning: Effects on organizational innovation to improve firm performance. Journal of Engineering and Technology Management, 29(3), 331-357.

Bourne, M., Mills, J., Wilcox, M., Neely, A., \& Platts, K. (2000). Designing, implementing and updating performance measurement systems. International journal of operations \& production management.

Brix, J. (2017). Exploring knowledge creation processes as a source of organizational learning: 
A longitudinal case study of a public innovation project. Scandinavian Journal of Management, 33(2), 113-127.

Chavez, R., Yu, W., Jacobs, M. A., \& Feng, M. (2017). Manufacturing capability and organizational performance: The role of entrepreneurial orientation. International Journal of Production Economics, 184, 33-46.

Dada, O., \& Fogg, H. (2016). Organizational learning, entrepreneurial orientation, and the role of university engagement in SMEs. International Small Business Journal, 34(1), 86-104.

Damanpour, F. (1991). Organizational innovation: A meta-analysis of effects of determinants and moderators. Academy of management journal, 34(3), 555-590.

De Stefano, M. C., Montes-Sancho, M. J., \& Busch, T. (2016). A natural resource-based view of climate change: Innovation challenges in the automobile industry. Journal of Cleaner Production, 139, 1436-1448.

Donkor, J., Donkor, G. N. A., Kankam-Kwarteng, C., \& Aidoo, E. (2018). Innovative capability, strategic goals and financial performance of SMEs in Ghana. Asia Pacific Journal of Innovation and Entrepreneurship.

Dzulfikar, M. F., Handayani, R. C., Syahrizal, A., Sensuse, D. I., Satria, D., \& Wulandari, I. A. (2018, August). The Role of Social Commerce Features and Customer Knowledge Management in Improving SME's Innovation Capability. In 2018 6th International Conference on Cyber and IT Service Management (CITSM) (pp. 1-6). IEEE.

Ford, D., \& Paladino, A. (2013). Enabling innovation through strategic synergies. Journal of Product Innovation Management, 30(6), 1058-1072.

Foss, K., \& Foss, N. J. (2004). The next step in the evolution of the RBV: Integration with transaction cost economics. management revue, 107-121.

Ghazilla, R. A. R., Sakundarini, N., Abdul-Rashid, S. H., Ayub, N. S., Olugu, E. U., \& Musa, S. N. (2015). Drivers and barriers analysis for green manufacturing practices in Malaysian SMEs: a preliminary findings. Procedia Cirp, 26, 658-663.

Giménez, J., Madrid-Guijarro, A., \& Duréndez, A. (2019). Competitive capabilities for the innovation and performance of Spanish construction companies. Sustainability, 11(19), 5475.

Gopalakrishnan, S., \& Damanpour, F. (1997). A review of innovation research in economics, sociology and technology management. Omega, 25(1), 15-28.

Guinot, J., Miralles, S., Rodríguez-Sánchez, A., \& Chiva, R. (2020). Do compassionate firms outperform? The role of organizational learning. Employee Relations: The International Journal.

Gupta, H., \& Barua, M. K. (2018). A framework to overcome barriers to green innovation in SMEs using BWM and Fuzzy TOPSIS. Science of the Total Environment, 633, 122-139.

Hamdan, A. (2018). Intellectual capital and firm performance. International Journal of Islamic and Middle Eastern Finance and Management.

Hamidi, F., \& Gharneh, N. S. (2017). Impact of co-creation on innovation capability and firm performance: a structural equation modeling. $A D$-minister, (30), 73-90.

HOANG, C. C., \& NGOC, B. H. (2019). The Relationship between Innovation Capability and Firm's Performance in Electronic Companies, Vietnam. The Journal of Asian Finance, Economics, and Business, 6(3), 295-304.

Hooi, L. W., \& Ngui, K. S. (2014). Enhancing organizational performance of Malaysian SMEs. International Journal of Manpower.

Hosseini, P., Wright, C. D., \& Bhaskaran, H. (2014). An optoelectronic framework enabled by low-dimensional phase-change films. Nature, 511(7508), 206-211. 
Huhtala, J. P., Sihvonen, A., Frösén, J., Jaakkola, M., \& Tikkanen, H. (2014). Market orientation, innovation capability and business performance: Insights from the global financial crisis. Baltic Journal of Management.

Husain, Z., Dayan, M., \& Di Benedetto, C. A. (2016). The impact of networking on competitiveness via organizational learning, employee innovativeness, and innovation process: A mediation model. Journal of Engineering and Technology Management, 40, 15-28.

Hussein, A. T. T., Singh, S. K., Farouk, S., \& Sohal, A. S. (2016). Knowledge sharing enablers, processes and firm innovation capability. Journal of Workplace Learning.

Inkinen, H. (2016). Review of empirical research on knowledge management practices and firm performance. Journal of knowledge management.

Ismail, N. A., Saud, M. B., \& Isa, M. A. M. (2017). INFLUENCING FACTORS ON MALAYSIAN MANUFACTURING SMES'PERFORMANCE. International Journal of Accounting, Finance and Business (IJAFB), 2(6), 80-92.

Jiménez-Jiménez, D., \& Sanz-Valle, R. (2011). Innovation, organizational learning, and performance. Journal of business research, 64(4), 408-417.

Kafetzopoulos, D., \& Psomas, E. (2015). The impact of innovation capability on the performance of manufacturing companies: The Greek case. Journal of Manufacturing Technology Management.

Kalmuk, G., \& Acar, A. Z. (2015). The mediating role of organizational learning capability on the relationship between innovation and firm's performance: A conceptual framework. Procedia-Social and Behavioral Sciences, 210, 164-169.

Kamaluddin, A., Arshad, R., Akmal Hasan, H., \& Abu Samah, S. A. (2016). Social capital and innovation capital: accountability towards small medium enterprises'(SMEs) sustainable performance. Management \& Accounting Review, 15(1), 1-28.

Kang, S. C., Morris, S. S., \& Snell, S. A. (2007). Relational archetypes, organizational learning, and value creation: Extending the human resource architecture. Academy of management review, 32(1), 236-256.

Khalique, M., Bontis, N., Shaari, J. A. N. B., Yaacob, M. R., \& Ngah, R. (2018). Intellectual capital and organisational performance in Malaysian knowledge-intensive SMEs. International Journal of Learning and Intellectual Capital, 15(1), 20-36.

Kim, K., Watkins, K. E., \& Lu, Z. L. (2017). The impact of a learning organization on performance. European Journal of Training and Development.

Kogut, B., \& Zander, U. (1992). Knowledge of the firm, combinative capabilities, and the replication of technology. Organization science, 3(3), 383-397.

Lampe, H. W., \& Hilgers, D. (2015). Trajectories of efficiency measurement: A bibliometric analysis of DEA and SFA. European journal of operational research, 240(1), 1-21.

Maktabi, S. H., \& Khazaei, A. (2014). The impact of organizational learning on organizational performance and organizational innovation: Evidence from Bank Industry of Iran. International Journal of Economy, Management and Social Sciences, 3(10), 569573.

Maldonado-Guzmán, G., Garza-Reyes, J. A., Pinzón-Castro, S. Y., \& Kumar, V. (2019). Innovation capabilities and performance: are they truly linked in SMEs?. International Journal of Innovation Science.

Mantok, S., Sekhon, H., Sahi, G. K., \& Jones, P. (2019). Entrepreneurial orientation and the mediating role of organisational learning amongst Indian S-SMEs. Journal of Small Business and Enterprise Development. 
Medsker, G. J., Williams, L. J., \& Holahan, P. J. (1994). A review of current practices for evaluating causal models in organizational behavior and human resources management research. Journal of management, 20(2), 439-464.

Migdadi, M. M., Zaid, M. K. A., Yousif, M., Almestarihi, R. D., \& Al-Hyari, K. (2017). An empirical examination of knowledge management processes and market orientation, innovation capability, and organisational performance: Insights from Jordan. Journal of Information \& Knowledge Management, 16(01), 1750002.

Mir, M., Casadesús, M., \& Petnji, L. H. (2016). The impact of standardized innovation management systems on innovation capability and business performance: An empirical study. Journal of Engineering and Technology Management, 41, 26-44.

Mohammad, H. I. (2019). Mediating effect of organizational learning and moderating role of environmental dynamism on the relationship between strategic change and firm performance. Journal of Strategy and Management.

Naala, M. I. N., Nordin, N., \& Omar, W. A. W. (2017). Innovation capability and firm performance relationship: A study of pls-structural equation modeling (PlsSem). International Journal of Organization \& Business Excellence, 2(1), 39-50.

Nafei, W. (2015). Meta-analysis of the impact of psychological capital on quality of work life and organizational citizenship behavior: A study on Sadat City University. International Journal of Business Administration, 6(2), 42.

Narsa, I. M. (2019). The effect of market orientation, innovation, organizational learning and entrepreneurship on firm performance. Journal of Entrepreneurship Education, 22(3), 113.

Nawaz, T., \& Haniffa, R. (2017). Determinants of financial performance of Islamic banks: an intellectual capital perspective. Journal of Islamic Accounting and Business Research.

Neely, A., Gregory, M., \& Platts, K. (1995). Performance measurement system design: a literature review and research agenda. International journal of operations \& production management.

Omar, N. A., Nazri, M. A., Alam, S. S., \& Ahmad, A. (2016). Assessing the factors influencing service innovation capabilities and performance. Information Management And Business Review, 8(4), 52-63.

Osman, C. A., \& Ngah, R. (2016). Assessing sustainable competitive advantage in relation with intellectual capital, knowledge management and innovativeness in women-owned SMEs in Malaysia. Journal of International Business, Economics and Entrepreneurship (JIBE), 1(1), 46-51.

Peteraf, M. A. (1993). The cornerstones of competitive advantage: a resource-based view. Strategic management journal, 14(3), 179-191.

Pongsathornwiwat, A., Jeenanunta, C., Huynh, V. N., \& Udomvitid, K. (2019). How collaborative routines improve dynamic innovation capability and performance in tourism industry? A path-dependent learning model. Asia Pacific Journal of Tourism Research, 24(4), 281-295.

Racela, O. C., \& Thoumrungroje, A. (2019). When do customer orientation and innovation capabilities matter? An investigation of contextual impacts. Asia Pacific Journal of Marketing and Logistics.

Radjenović, T., \& Krstić, B. (2017). Intellectual capital as the source of competitive advantage: the resource-based view. Facta Universitatis, Series: Economics and Organization, 127137.

Rehman, S. U., Bhatti, A., \& Chaudhry, N. I. (2019). Mediating effect of innovative culture and 
organizational learning between leadership styles at third-order and organizational performance in Malaysian SMEs. Journal of Global Entrepreneurship Research, 9(1), 124.

Richard, P. J., Devinney, T. M., Yip, G. S., \& Johnson, G. (2009). Measuring organizational performance: Towards methodological best practice. Journal of management, 35(3), 718-804.

Satiman, L. H., Mansor, N. N. A., \& Zulkifli, N. (2015). Return on Investment (ROI) training evaluation in Malaysian SMEs: factors influencing the adoption process. Development and learning in Organizations.

Saunila, M. (2016). Performance measurement approach for innovation capability in SMEs. International Journal of Productivity and Performance Management.

Senge, P., Roberts, C., Ross, R. B., Smith, B. J., \& Kleiner, A. (1994). The fifth discipline fieldbook. New York' Doubleday Publ.

Senge, P.M. (1990), The Fifth Discipline: Art and Practice of the Learning Organization, Doubleday, New York, NY.

Shurafa, R., \& Mohamed, R. B. (2016). Management control system, organizational learning, and firm's performance: An empirical study from developing economy. International Journal of Advanced and Applied Sciences, 3(10), 79-88.

Siddique, C. M. (2018). Learning organization and firm performance: Making a business case for the learning organization concept in the United Arab Emirates. International Journal of Emerging Markets.

Singh, H., \& Mahmood, R. (2014). Combined effect of competitive and manufacturing strategies on export performance of small and medium enterprises in Malaysia. Global Journal of Management and Business Research.

Singh, S., Darwish, T. K., \& Potočnik, K. (2016). Measuring organizational performance: A case for subjective measures. British Journal of Management, 27(1), 214-224.

Standing, C., \& Kiniti, S. (2011). How can organizations use wikis for innovation?. Technovation, 31(7), 287-295.

Taherparvar, N., Esmaeilpour, R., \& Dostar, M. (2014). Customer knowledge management, innovation capability and business performance: a case study of the banking industry. Journal of knowledge management.

Tahir, H. M., Razak, N. A., \& Rentah, F. (2018). The contributions of small and medium enterprises (SME's) On Malaysian economic growth: A sectoral analysis. In International Conference on Kansei Engineering \& Emotion Research (pp. 704-711). Springer, Singapore.

Tuan, N., Nhan, N., Giang, P., \& Ngoc, N. (2016). The effects of innovation on firm performance of supporting industries in Hanoi, Vietnam. Journal of Industrial Engineering and Management, 9(2), 413-431.

Valdez-Juárez, L. E., Gallardo-Vázquez, D., \& Ramos-Escobar, E. A. (2019). Organizational learning and corporate social responsibility drivers of performance in SMEs in Northwestern Mexico. Sustainability, 11(20), 5655.

Verdolini, E., Bak, C., Ruet, J., \& Venkatachalam, A. (2018). Innovative green-technology SMEs as an opportunity to promote financial de-risking. Economics: The Open-Access, OpenAssessment E-Journal, 12(2018-14), 1-13.

Wang, Z., Wang, N., \& Liang, H. (2014). Knowledge sharing, intellectual capital and firm performance. Management decision.

Wernerfelt, B. (1984). A resource-based view of the firm. Strategic management journal, 5(2), 
171-180.

Yu, C. P., Zhang, Z. G., \& Shen, H. (2017). The effect of organizational learning and knowledge management innovation on SMEs' technological capability. Eurasia Journal of Mathematics, Science and Technology Education, 13(8), 5475-5487.

Yusoff, Y. M., Omar, M. K., \& Zaman, M. D. K. (2019). Does organizational learning capability allow improving business sustainability? A quantitative analysis in the manufacturing SME context. In IOP Conference Series: Materials Science and Engineering (Vol. 469, No. 1, p. 012015). IOP Publishing.

Zandi, G., \& Sulaiman, M. (2015). Does organizational learning matter?. International Journal of Management and Sustainability, 4(5), 114. 